Комитас большое значение придавал воспитанию, считая, что преступниками люди становятся в результате неправильного воспитания. История человечества знает много случаев, когда гениальность преступников проявляется и в местах заключения

"Педагог должен владеть материалом, который он преподает" [1,стр. 79]. Сегодня это замечание кажется наивным. Однако 1912 году такое требование к педагогу, к его работе было не очень легко выполнимым, а ярким примером этого был сам Комитас, со своими энциклопедическими знаниями.

Поражает вывод и призыв, с которым Комитас обращается к учителям: "Осмотрительно и с осторожностью относитесь к делу воспитания: слишком уязвимая эта область. Вы призваны воспитать поколение, которое-будущая нация. Неправильным воспитанием погубите нацию " [1, стр. 79]. Пожалуй никто не будет оспаривать этот тезис. Однако, согласиться это одно, и совершенно другое-осуществить это каждый день, каждый час, сознавая важность каждодневной работы во имя будущего нации.

Именно в этом проявляется роль и значение педагогических взлядов великоо Комитаса вардапета, которые актуальны и в наше неспокойное время, и не только для армянскоо народа, т. к. в них отражается прошлое, настоящее и будущее человечества.

$$
\text { *** }
$$

1. Комитас- Армянин имеет самобытную музыку. Исследования и статьи, кн. II. Ереван, 2007г. (на армянском языке).

2. Комитас в воспоминаниях современников. Ереван, 2009г. (на армянском языке).

3. Шавердян А.-Комитас, Москва, 1989г.

4. Барсамян А., Арутюнян М.- История армянской музыки, Ереван, 1996г. (на армянском языке).

5. Мурадян М.- Армянская музыка в конце XIX и начале XX веков. Ереван, 1970г. (на армянском языке).

\title{
Соловей А.И. \\ Культура стилевого мышления как компонент профессиональной культуры музыканта
}

МГИМ им. А.Г. Шнитке

(Россия, Москва)

doi: $10.18411 / \mathrm{j}-30-09-2017-40$

idsp: 000001:lj-30-09-2017-40

\section{Аннотация}

Каждый профессиональный музыкант - композитор, исполнитель, педагог, исследователь, организатор творческих проектов - неизбежно сталкивается в своей творческой деятельности с проблемой стиля, что позволяет рассматривать культуру стилевого мышления как компонент профессиональной культуры музыканта, как возможность свободно ориентироваться в художественном пространстве нашего времени. Однако, как и каждая категория в системе гуманитарного знания, понятие «культура стилевого мышления» требует выявления его сущностных характеристик. Целью представленной статьи является определение содержания понятия «культура стилевого мышления», роли культуры стилевого мышления в творческом самоосуществлении музыканта, механизмов влияния на процесс его творческого становления и самореализации.

Ключевые слова: культура стилевого мышления, музыкальное мышление, музыкальный язык, музыкальная речь, творческое становление, творческое общение, творческий диалог.

Выявление сущностных характеристик понятия «культура стилевого мышления» как компонента профессиональной культуры музыканта требует, в первую очередь, обращения к рассмотрению таких значимых категорий, как «музыкальное мышление», 
«музыкальный язык», «музыкальная речь». И если согласиться с Л.С. Выготским в том, что центральным моментом проблемы мышления и речи является вопрос об отношении мысли к слову, то у музыканта-исследователя, естественно, возникает вопрос о взаимоотношениях музыкальной мысли и музыкального слова $[10$, с.8].

Тем более, что представляется совершенно справедливым убеждение психолога в том, что «мышление и речь оказываются ключом к пониманию природы человеческого сознания», которое, по мнению Выготского, «отображает себя в слове, как солнце в малой капле воды. Слово относится к сознанию, как малый мир к большому, как живая клетка к организму, как атом к космосу. Оно и есть малый мир сознания. Осмысленное слово есть микрокосм человеческого сознания» $[10$, с.336].

Осмысленное музыкальное слово являет собой ключ к пониманию музыкального сочинения как части бесконечного художественного космоса, которым является музыка как вид искусства. Обращаясь к психологической природе значения слова, Выготский замечает, что «слово всегда относится не к одному какому-нибудь отдельному предмету, но к целой группе или к целому классу предметов. В силу этого каждое слово представляет собой скрытое обобщение, всякое слово уже обобщает, а с психологической точки зрения значение слова прежде всего представляет собой обобщение. Но обобщение, как это легко видеть, есть чрезвычайный словесный акт мысли, отражающий действительность совершенно иначе, чем она отражается в непосредственных ощущениях и восприятиях» $[10$, с. 14$]$.

Это в полной мере можно отнести и к музыкальному слову, которое, несомненно, являет собой обобщение, выражающее направленность музыкальной мысли. И если музыкальное слово - это акт музыкальной мысли, который отражает некую «музыкальную действительность», то вполне правомерно предположить, что и в данном случае эта действительность может отражаться совершенно иначе, чем в привычных ощущениях и представлениях. Новая музыкальная мысль, выраженная посредством нового музыкального слова, способствует рождению нового стиля, преображающего художественное пространство и определяющего новые направления развития музыки как динамичной системы, находящейся в постоянном движении и развитии.

Поэтому понятно, что рассматривать все ранее перечисленные понятия необходимо в их взаимосвязи со стилем в музыке, его рождением и самоутверждением, его способностью преображать художественное пространство культуры, что часто становится препятствием для его осмысления и оценки. Эта достаточно часто возникающая проблема, которая, в сущности, и определяет актуальность и значимость задачи формирования и развития стилевого мышления у современного музыканта, что требует, в свою очередь, изучения и анализа функций стиля, существующих детерминант его, объективных и субъективных факторов, связанных с этим понятием.

Также необходимо в процессе формирования культуры стилевого мышления музыканта-инструменталиста обращение к типологии стиля, что включает в себя такие вопросы, как авторский, национальный и исторический стили. Кроме того, процесс формирования и развития культуры стилевого мышления требует применения ряда методов, позволяющих глубоко проникать в стилевые пласты художественного пространства культуры, осуществлять сравнительные стилевые характеристики, проводить стилевой анализ изучаемого художественного текста, что становится фундаментом для создания яркой исполнительской интерпретации музыкального произведения.

Итак, вновь обратимся к «музыкальному мышлению» - сложнейшей сфере, определяющей стратегическую направленность профессиональной деятельности музыканта, изучению которой посвящено множество работ. Опираясь на определение, данное Н.А. Леонтьевым, согласно которому, мышление являет собой форму психической деятельности сознания, каждый из музыкантов-исследователей стремится выявить специфику музыкального мышления. Эту задачу ставит в своих работах М.Г. Арановский, 
рассматривая структуру творческого процесса [2], анализируя свойства музыкального текста и выявляя музыкальную логику, которую исследователь интерпретирует как явление культуры[3]. У В. Барского мы находим определение хроматики как категории музыкального мышления [4], а И.А. Барсова обращается к сфере музыкального мышления, размышляя о специфике языка музыки и его роли в создании художественной картины мира[5].

К сфере музыкального мышления обращается и И. Беленкова, представляя возможности рассмотрения музыкального текста как семиотического объекта [6].. В. Блудова рассматривает творческое мышление в контексте природы художественного восприятия [7]. М. Бонфельд определяет художественно-творческое мышление как теоретическая и практическую проблему, изучение которой необходимо каждому профессиональному музыканту[8].

Анализируя в своей фундаментальной работе «Музыка: Язык. Речь. Мышление» роль музыкального мышления в М.Ш. Бонфельд в различных сферах музыкальной деятельности (музицирования, включающего в себя сочинение и исполнение музыки, и восприятия ее в качестве слушателя или исследователя музыкального текста), сразу обращает внимание на специфику каждой из этих областей. Так, по его мнению, «музицирование, в частности, представляет собой духовно-практическую деятельность, в рамках которой все, что связано с мышлением - идеальным, психически активным процессом, протекающим в сознании (подсознании) творца или исполнителя, - сочетается c работой сугубо практической, выходящей за рамки идеально-мыслительной деятельности»[9, с. 7].

Из этого следует, что формирование культуры стилевого мышления музыканта являет собой сложный, целостный процесс, объединяющий в неразрывный сплав идеальное и материальное начала, теорию и практику, поскольку исполнение требует материализации идей, рожденных в процессе идеальной психической деятельности. Это очень важный аспект осуществляемой работы, требующий постоянного внимания, направленного на преодоления дихотомии идеального и материального, достижения равновесия, обеспечивающего эффективность учебно-воспитательного процесса.

Не менее сложен и процесс восприятия, поскольку, как справедливо полагает М.Ш. Бонфельд, «его никоим образом нельзя рассматривать только как пассивное следование слушательского сознания за реализующимся в конкретном музыкальном произведении процессом развертывания музыкальной мысли»[9, с.7] . Пассивное восприятие предполагает отношение к музыке как к некоему фону, не задевающему сознание, не включающему ни эмоциональную, ни интеллектуальную сферу личности. Такое отношение иногда можно наблюдать, но вправе ли мы в таком случае называть такой слушательский процесс восприятием? Ведь в этом случае музыкальное произведение не оставляет ни эмоционального, ни интеллектуального отклика, а это значит, что заложенное в нем музыкальное послание остается не принятым.

Именно поэтому М.Ш. Бонфельд настаивает на том, что музыкальное восприятие неизбежно включает в себя различные компоненты мыслительной деятельности, «которые, взятые в совокупности, образуют по отношению к мысленному следованию за звучащей музыкой как бы встречный поток мысли который находится с первым в постоянном более или менее тесном контакте»[9, с. 7].

При этом Бонфельд уточняет, что слово «встречный» в данном контексте трактуется не как направленный в противоположную сторону, а, напротив, как противостоящий, дополняющий высказанную музыкальную мысль личностным смыслом. Таким образом, процесс восприятия, процесс постижения музыкального сочинения - это встреча двух потоков мысли, вступающих в творческое общение, творческий диалог. Это замечание очень важно для осмысления процесса формирования и развития культуры стилевого мышления музыканта-инструменталиста, поскольку «встречный поток», его 
интенсивность, его четкая направленность определяют направление в создании как слушательской, так и исполнительской интерпретации музыкального произведения.

Однако, Бонфельд обращает особое внимание исследователей на двоякий результат взаимодействия следования за музыкальной мыслью и встречного мысленного потока. Он считает, что «возможно - но не обязательно, - оно усиливает музыкальные впечатления, однако одновременно присутствует и противоположный эффект встречный поток становится шумом, заглушающим, искажающим (хотя бы незначительно) музыкальный смысл произведения. Как известно, эффект шума неизбежен при передаче любого сообщения» [9, с. 7]. Что же такое «эффект шума» в ситуации постижения музыки? В интерпретации Бонфельда - это присутствие в момент ее восприятия не только целого ряда музыкальных ассоциаций, но и появление различных мыслей из других сфер, не имеющих отношения к музыке. Не является редкостью ситуация, «когда слушатель при восприятии погружается в собственные мысли, и его сознание отключается от звучащей музыки, в этом случае внемузыкальные факторы мышления просто вытесняют музыкальные» [9, с. 8].

Это действительно случается в том случае, когда (по тем или иным причинам) музыка не захватывает полностью внимание слушателя: он отвлекается, погружается в собственный мир, происходит некое отторжение от того звучащего пространства, куда его приглашает музыкальное слово, которое он слышит, но не понимает. Очень часто это происходит именно потому, что логика развития музыкальных идей ускользает от слушателя, он не ориентируется в предлагаемом ему звуковом потоке, не улавливает его смысл и не наполняет его личностным смыслом. Не находя привычных ориентиров, он теряет интерес, а иногда даже и начинает испытывать враждебность к этому чужому миру, где для него нет места.

К сожалению, это не всегда удел не достаточно образованных любителей музыки. Музыкант, не обладающий значительным профессиональным кругозором, настроенный на ограниченный круг стилевых ориентиров, сознательно (или бессознательно) возводит защитную стену между собой и чуждой ему музыкой. Такой стеной и становится эффект шума, эффект отторжения от непонятного и чуждого ему музыкального слова, музыкальной речи, музыкальной мысли. Он слушает музыкальное сочинение, но не слышит его. А это значит, что он, не обладает должным уровнем стилевого мышления, сформированность которого становится ключом, открывающим беспредельность художественного пространства, куда приглашает его музыка,

Обращаясь к проблеме стиля и жанра в музыке, Е.В. Назйкинский задает себе и каждому из нас целый ряд вопросов: «Что есть стиль? Что значит это слово для музыканта - композитора, пианиста, дирижера, критика, педагога? Как соотносятся исторические и национальные стили со стилями авторскими, индивидуальными, а последние с «возрастными» - раним, зрелым и поздним? В чем специфические отличия стиля от языка, как он связан с формой и содержанием художественных творений??»[11. с.9]. Е.В. Назайкинский совершенно справедливо полагает, что «эти и многие другие подобные приведенным вопросы неизбежно возникают при исследовании музыкальных произведений и их исполнении, при изучении рукописей и различных редакторских версий нотного текста, при обращении к вопросам музыкального восприятия и воспитания» $[11$, с.9]. И не случайно Е.В. Назайкинский сетует на то, что «ее величество Практика» часто стремится обходиться без обращения к проблемам стиля, полагая, что «стилевые процессы, события, взаимодействия совершаются сами собой, , естественно, по законам музыкальной жизни и культуры как природно-социального организма, совершаются как бы без вмешательства аналитического ока наблюдателя»[11, с.9].

И это не есть просто заблуждение «ее величества Практики», это часто весьма агрессивная позиция не только любителей, но и весьма часто знатоков, профессионалов, среди которых во все времена находились радетели за чистоту музыкального стиля, обвиняющие творцов нового музыкального пространства в разрушении основ музыки, в 
«сумбуре вместо музыки» и т.д.. А между тем, хотим мы того или не хотим, но музыка как сложная саморазвивающаяся система, несмотря ни на какие препятствия, постоянно находится в движении и развитии, отбрасывая на обочину всех, кто стремится помешать ,этому процессу.

Но действительно ли может «ее величество Практика» обойтись без аналитического взгляда наблюдателя? Ведь если разговор идет о слушателе, любителе музыки, то даже в этом случае невозможно принять «музыкальное послание», если у него отсутствует представление о стиле постигаемого музыкального произведения, если он настроен на другую «стилевую волну» и совершенно не готов открыть «заветную дверь» в незнакомый для него художественный мир. Однако, следует признать, что для любителя музыки часто бывает вполне достаточно (такой точки зрения придерживался Т. Адорно) достижение уровня «хорошего слушателя», который «понимает музыку примерно так, как люди понимают родной язык, - ничего не зная или зная мало о грамматике и синтаксисе - неосознанно владея имманентной музыкальной логикой» [1, с. 14].

Но это возможно, как уже мы выяснили ранее, только в том случае, если любитель музыки обладает немалым слушательским опытом, позволяющим ему воспринимать музыку разных направлений и стилей. Только тогда он может (пусть и неосознанно) следовать за логикой развития музыкальных идей. Иначе музыка, лишенная привычных слуху взаимосвязей, воспринимается как иностранный язык который ощущается слушателем как бессвязный набор звуков, не несущих в себе никакой смысловой нагрузки. Но если «ее величество Практика» иногда и позволяет хорошему слушателю обойтись без серьезного аналитического взгляда, то можно ли считать, что профессиональному музыканту позволительно понимать музыку, как понимают родной язык, не владея при этом «грамматикой и синтаксисом» музыкальной речи?

Казалось бы ответ на это вопрос очевиден и не требует доказательств. А между тем исполнительская практика иногда предлагает нам интерпретации, который свидетельствуют о том, что грамматика и синтаксис музыкального языка исполняемого сочинения неведомы исполнителю, что он живет и действует совершенно в ином стилевом пространстве, чрезвычайно далеком от мира, созданного автором. Т. Адорно, классифицируя различные типы отношения к музыке, выдвигает в качестве высшего тип слушателя-эксперта, которого он характеризует как вполне сознательного слушателя. «от сознания которого не ускользает ничто и который в каждый конкретный момент отдает себе отчет в том, что слышит»[1, с. 14].

Если мы обратимся к музыкально-исполнительской или музыкальнопедагогической сфере, то здесь вполне уместно настаивать на том, что подлинный профессионал - это обязательно «эксперт», для которого открыты двери в стилевое пространство постигаемой им музыки. Преодолев знаковую и конструктивную грани музыкальной формы, он уверенно входит в мир художественных образов автора, изъясняющихся на понятном для него языке. Он готов к диалогу с ними, в процессе которого рождается новое художественное пространство, обогащенное его чувствами, его идеями, но при этом не противоречащее замыслу автора.

Подводя итоги всему вышеизложенному, можно сформулировать сущностные особенности понятия «культура стилевого мышления музыканта -инструменталиста» как сложное интегративное, свойство личности, определяющее способность музыканта понимать и толковать музыкальный текст, успешно преодолевать знаковую и конструктивную грань музыкальной формы, проникать в образную сферу, свободно ориентироваться в ней, понимая логику и стилевые особенности постигаемого мира, его встроенность в целостное пространство музыкальной культуры. Культура стилевого мышления является неотъемлемым компонентом профессиональной культуры музыканта, в значительной мере определяющим его творческое становление, профессиональное 
самоопределение и успешную самореализацию и самоактуализацию в дальнейшей профессиональной деятельности.

$$
* * *
$$

1. Адорно, Т. В. Типы отношения к музыке / Т.В. Адорно //Избранное: социология музыки. - М.: СПб.: Университетская книга, 1999. - С. 11-26.

2. Арановский, М.Г. К вопросу о структуре творческого процесса / М.Г. Арановский // Проблемы музыкального мышления и восприятия. - Ташкент, 1972. С. 1-7.

3. Арановский, М.Г. К изучению музыкальной логики как явления культуры /М.Г. Арановский // Методологические проблемы науки и культуры. - Куйбышев, 1979. Вып.4. С. 140-150.

4. Барский, В. Хроматика как категория музыкального мышления / В. Барский // M.: LAUDAMUS, 1992. C, 114-120.

5. Барсова, И.А. Специфика языка музыки в создании художественной картины мира / И.А. Барсова //XТ, 1984, Л.., 1986. С. 99-116.

6. Беленкова, И. О некоторых возможностяхрассмотрения музыки как семиотического объекта / И. Беленкова // Укр. Музикознавство, Киев, 1977. Вып. 12. С. 76-90.

7. Блудова, В. Природа художественного восприятия / В. Блудова // М.: ЭО, 1977. Вып. 4. С. 114-152.

8. Бонфельд, М. Художественное творческое мышление как теоретическкая и практическая проблема / М, Бонфельд // Психология-практике: Тезисы 1-й Региональной школы-семинара. - Вологда, 1989. С. 7-10.

9. Бонфельд, М.Ш. Музыка: Язык. Речь. Мышление. Опыт системного анализа. Монография / М.Ш. Бонфельд. - СПб.: Композитор*Санкт-Петербург, 2006. - 648 с.

10. Выготский, Л.С. Мышление и речь / Л.С. Выготский. - М.: Лабиринт. - 352 с.

11. Назайкинский, Е.В. Стиль и жанр в музыке. Учебное пособие для студентов высших учебных заведений / Е.В. Назайкинский. - М.: ВЛАДОС, 2003. - 248, нот. 